\title{
Synthesis and characterization of two oxo-bridged oxo(arylimido) [tris(3,5-dimethylpyrazolyl)borato]molybdenum(V) complexes and crystal structure of $[\mathrm{MoTp} *(\mathrm{O}) \mathrm{Cl}](\mu-\mathrm{O})\left[\mathrm{MoTp} *(\mathrm{Cl})\left(\equiv \mathrm{NC}_{6} \mathrm{H}_{4} \mathrm{OMe}\right)\right]$
}

\author{
Isil Topaloglu Sozuer* and Alev Gunyar \\ Department of Chemistry, Faculty of Science, Izmir Institute of Technology, Izmir, Turkey
}

John J. Jeffery and Hayrullah Hamidov

School of Chemistry, University of Bristol, England

Received 16 April 2004; accepted 28 April 2004

\begin{abstract}
Reaction of the oxo-molybdenum(V) compound, [MoTp*(O)Cl $]$, [Tp* = hydrotris(3,5-dimethylpyrazol-1-yl)borate] with $p$-methoxy and $p$-nitroaniline in the presence of $\mathrm{Et}_{3} \mathrm{~N}$ under $\mathrm{N}_{2}$, afforded the oxo-bridged oxo(arylimido) molybdenum(V) complexes, [MoTp*(O)Cl] $(\mu-\mathrm{O})\left[\mathrm{MoTp} *(\mathrm{Cl})\left(\equiv \mathrm{NC}_{6} \mathrm{H}_{4} \mathrm{R}\right)\right]\left(1, \mathrm{R}=\mathrm{OMe} ; 2, \mathrm{R}=\mathrm{NO}_{2}\right)$. The new compounds were characterized by elemental analysis, i.r., mass, and ${ }^{1}$ H-n.m.r. spectra. The single crystal X-ray crystallographic determination of $[\mathrm{MoTp} *(\mathrm{O}) \mathrm{Cl}](\mu-\mathrm{O})\left[\mathrm{MoTp} *(\mathrm{Cl})\left(\equiv \mathrm{NC}_{6} \mathrm{H}_{4} \mathrm{OMe}\right)\right]$ was carried out to confirm that there is a $\mathrm{Mo}-\mathrm{O}-\mathrm{Mo}$ bridge and a near linear arylimido group in the structure.
\end{abstract}

\section{Introduction}

The tris(pyrazolyl)borate ligand was first synthesised by Trofimenko [1] and has assumed an important role in modern coordination chemistry [2]. It has been shown that there are strong analogies between the behaviour of metal complexes containing trispyrazolborato anions, and those containing the $\eta^{5}$-cyclopentadienyl ligand [1]. This ligand system has widely been used in inorganic and organometallic chemistry especially with $\mathrm{d}$ and $\mathrm{f}$ transition elements [3]. It was known that tris(pyrazolyl)borate ligands had a significant impact on the modeling of the active centre of Mo enzymes [4]. Also these ligands exhibit dynamic behaviour on the n.m.r. timescale [5]. The sterically encumbering nature of the $\mathrm{Tp}$ * (hydrotris(3,5-dimethylpyrazol-1-yl)borate) ligand compared with $\mathrm{Cp}$ * (pentamethylcyclopentadienyl) is widely known and explored in high activity for catalyst systems $[6,7]$.

Molybdenum, considered as a trace element, presents several oxidation states, and therefore may change easily its coordination number to form mono and binuclear oxo complexes which is of great importance from basic as well as applied points of view. The propensity of oxomolybdenum species in higher oxidation states to form di, tri and polynuclear complexes is well known [8]. Molybdenum is a relevant element for the synthesis of many homogeneous and heteregenous catalysts. The element is also essential in several enzymatic systems. One of the characteristics of the molybdenum chemistry is related to the easy conversion between its oxidation

\footnotetext{
*Author for correspondence
}

states and to the changes of coordination number, observed particularly between $\mathrm{Mo}(\mathrm{III}), \mathrm{Mo}(\mathrm{IV}), \mathrm{Mo}(\mathrm{V})$ and $\mathrm{Mo}(\mathrm{VI})$. The chemistry of oxoMo(V) complexes is of importance especially in industrial and biochemical catalysis [9].

Recently, interest in the chemistry of transition metal compounds that contain multiple bonded ligands has increased greatly due mainly to their involvement in many important reactions. Although quite a large number of bis(imido) [10-15] and dioxo [16] complexes of molybdenum are known, there is only a small amount of information on the related mixed terminal oxo-imido compounds [17-23]. Although a number of systems involving $\mu$-ligation in the presence of terminal imido groups have previously been reported [23-30], only a few examples of molybdenum compounds containing both imido ligands and tris(pyrazolyl)borate co-ligand were known [17, 31, 32]. However, the area of $\mu$-оxo complexes containing mixed oxo-arylimido ligands and Tp* co-ligand is still largely unexplored.

In the present paper, we report the synthesis and spectroscopic characterization of two novel binuclear oxo-bridged oxo(arylimido) molybdenum complexes $\left[\mathrm{MoTp}^{*}(\mathrm{O}) \mathrm{Cl}\right](\mu-\mathrm{O})\left[\mathrm{MoTp} *(\mathrm{Cl})\left(\equiv \mathrm{NC}_{6} \mathrm{H}_{4} \mathrm{R}\right)\right](\mathrm{R}=\mathrm{OMe}$, $\mathrm{NO}_{2}$ ) and the X-ray crystal structure of [MoTp*$(\mathrm{O}) \mathrm{Cl}](\mu-\mathrm{O})\left[\mathrm{MoTp}^{*}(\mathrm{Cl})\left(\equiv \mathrm{NC}_{6} \mathrm{H}_{4} \mathrm{OMe}\right)\right]$.

\section{Experimental}

All preparations and manipulations were carried out using Schlenk techniques under an oxygen-free nitrogen 
atmosphere. All glassware was oven-dried at $120^{\circ} \mathrm{C}$. Solvents were dried by standard procedures, distilled and kept under nitrogen over $4 \AA$ molecular sieves.

The starting material $\left[\mathrm{MoTp}^{*}(\mathrm{O}) \mathrm{Cl}_{2}\right]$ was prepared according to Enamark's published method [33].

I.r. spectra were recorded on a Magna IR spectrophotometer as pressed $\mathrm{KBr}$ disks. ${ }^{1} \mathrm{H}$-n.m.r. spectra were recorded in $\mathrm{CDCl}_{3}$ on $400 \mathrm{MHz}$ High Performance Digital f.t.-n.m.r. at TUBITAK (Research Council of Turkey). Mass spectra analyses were performed on Joel AX505 FAB device using Xe at $3 \mathrm{kV}$ positive ion matrix $m$-NBA ( $m$-nitrobenzyl alcohol). Elemental analysis were carried out by using a LECO CHNS 932 instrument. The crystal structure determination was done using a Bruker SMART CCD area-dedector diffractometer.

All yields are based on the starting material-containing compound.

$\left[\mathrm{MoTp}^{*}(\mathrm{O}) \mathrm{Cl}\right](\mu-\mathrm{O})\left[\mathrm{MoTp} *(\mathrm{Cl})\left(\equiv \mathrm{NC}_{6} \mathrm{H}_{4} \mathrm{OMe}\right)\right]$ (1)

A mixture of $\left[\mathrm{MoTp} *(\mathrm{O}) \mathrm{Cl}_{2}\right] \quad(0.3 \mathrm{~g}, \quad 0.60 \mathrm{mmol})$, 4-methoxyaniline $(0.14 \mathrm{~g}, 1.20 \mathrm{mmol})$ and dry $\mathrm{Et}_{3} \mathrm{~N}$ $\left(0.6 \mathrm{~cm}^{3}, 0.42 \mathrm{mmol}\right)$ in dry toluene $\left(20 \mathrm{~cm}^{3}\right)$ was heated to reflux with stirring under $\mathrm{N}_{2}$ for $c a .14 \mathrm{~h}$, during which time the solution became dark red-brown. The mixture was then cooled, filtered and evaporated to dryness. The residue was dissolved in $\mathrm{CH}_{2} \mathrm{Cl}_{2}$ and chromatographed on silica gel using $\mathrm{CH}_{2} \mathrm{Cl}_{2} / n$-hexane $(9: 1, \mathrm{v} / \mathrm{v})$ as eluant. The red-brown fraction was collected, crystallised from $\mathrm{CH}_{2} \mathrm{Cl}_{2} / n$-hexane to yield $[\mathrm{MoTp} *(\mathrm{O}) \mathrm{Cl}](\mu-\mathrm{O})\left[\mathrm{MoTp} *(\mathrm{Cl})\left(\equiv \mathrm{NC}_{6} \mathrm{H}_{4} \mathrm{OMe}\right)\right]$, as dark red microcrystals, $0.15 \mathrm{~g}(51 \%)$.

$$
\left[\mathrm{MoTp}^{*}(\mathrm{O}) \mathrm{Cl}\right](\mu-\mathrm{O})\left[\mathrm{MoTp} *(\mathrm{Cl})\left(\equiv \mathrm{NC}_{6} \mathrm{H}_{4} \mathrm{NO}_{2}\right)\right] \text { (2) }
$$

A mixture of $\left[\mathrm{MoTp}^{*}(\mathrm{O}) \mathrm{Cl}_{2}\right](0.3 \mathrm{~g}, \quad 0.60 \mathrm{mmol})$, 4-nitroaniline $(0.16 \mathrm{~g}, 1.21 \mathrm{mmol})$ and dry $\mathrm{Et}_{3} \mathrm{~N}$ $\left(0.6 \mathrm{~cm}^{3}, 0.42 \mathrm{mmol}\right)$ in dry toluene $\left(20 \mathrm{~cm}^{3}\right)$ was heated to reflux with stirring under $\mathrm{N}_{2}$ for $16 \mathrm{~h}$. The reaction was followed by tlc using the procedure described above for (1) to yield [MoTp*(O)Cl] $(\mu-\mathrm{O})[\mathrm{MoTp} *(\mathrm{Cl})$ $\left.\left(\equiv \mathrm{NC}_{6} \mathrm{H}_{4} \mathrm{NO}_{2}\right)\right]$ as brown microcrystals, $0.12 \mathrm{~g}(40 \%)$.

\section{Results and discussion}

\section{Synthetic studies}

Reaction of $\left[\mathrm{MoTp}^{*}(\mathrm{O}) \mathrm{Cl}_{2}\right]$ with $\mathrm{H}_{2} \mathrm{NC}_{6} \mathrm{H}_{4} \mathrm{R}$ $\left(\mathrm{R}=\mathrm{OMe}\right.$ and $\left.\mathrm{NO}_{2}\right)$ in the presence of triethylamine in toluene produced oxo-bridged oxo(arylimido)-molybdenum complexes $[\mathrm{MoTp} *(\mathrm{O}) \mathrm{Cl}](\mu-\mathrm{O})[\mathrm{MoTp} *(\mathrm{Cl})$ $\left.\left(\equiv \mathrm{NC}_{6} \mathrm{H}_{4} \mathrm{R}\right)\right]\left(\mathrm{R}=\mathrm{OMe}, \mathrm{NO}_{2}\right)$. The reactions were performed at the reflux temperature over periods ranging from 14 to $16 \mathrm{~h}$. Formation of the complexes was followed by thin layer chromatography, tlc, using $\mathrm{CH}_{2} \mathrm{Cl}_{2} / n$-hexane (v:v, different ratios) as eluant. The products were readily purified by column chromatography on silica gel 60 (70-230 mesh) using the same solvent mixture. The complexes are air-stable and soluble in chlorinated solvents.

The previously reported mononuclear oxo(arylimido) molybdenum(VI) trispyrazolborate complexes, [MoTp*$(\mathrm{O}) \mathrm{Cl}(=\mathrm{NR})]\left(\mathrm{R}=4\right.$-tolyl, $\left.\mathrm{C}_{6} \mathrm{H}_{4} \mathrm{NMe}_{2}-4\right)$, containing mixed oxo-imido ligands and the $\mathrm{Tp}^{*}$ co-ligand, were prepared by the reaction of $\left[\mathrm{MoTp}^{*}(\mathrm{O}) \mathrm{Cl}_{2}\right]$ with two equivalents of $\mathrm{RNH}_{2}$ in the presence of $\mathrm{Et}_{3} \mathrm{~N}$ [17]. Therefore, the formation of oxo-bridged molybdenum $(\mathrm{V})$ compounds, $[\mathrm{MoTp} *(\mathrm{O}) \mathrm{Cl}](\mu-\mathrm{O})[\mathrm{MoTp} *(\mathrm{Cl})$ $\left.\left(\equiv \mathrm{NC}_{6} \mathrm{H}_{4} \mathrm{R}\right)\right],\left[(1) \mathrm{R}=\mathrm{OMe}\right.$; (2) $\mathrm{R}=\mathrm{NO}_{2}$ ] containing both terminal oxo, imido group and $\mathrm{Tp}^{*}$ co-ligand by double deprotonation of amines is of interest and are the first examples for mixed oxo-arylimido $\mathrm{Mo}(\mathrm{V})$ compounds containing the $\mathrm{Tp}^{*}$ co-ligand. The synthetic route shown in Scheme 1 can be suggested for the formation of complexes (1) and (2).

\section{Spectroscopic studies}

Molecular ion peaks (Table 1) determined from the mass spectrometric data are in accord with the suggested structure for $[\mathrm{MoTp} *(\mathrm{O}) \mathrm{Cl}](\mu-\mathrm{O})\left[\mathrm{MoTp} *(\mathrm{Cl})\left(\equiv \mathrm{NC}_{6} \mathrm{H}_{4}-\right.\right.$ $\left.\mathrm{NO}_{2}\right)$ ] and the structure obtained by the X-ray structure of $[\mathrm{MoTp} *(\mathrm{O}) \mathrm{Cl}](\mu-\mathrm{O})\left[\mathrm{MoTp} *(\mathrm{Cl})\left(\equiv \mathrm{NC}_{6} \mathrm{H}_{4} \mathrm{OMe}\right)\right]$ (Figure 1).

I.r. spectral data (Table 2) for the complexes [MoTp*$(\mathrm{O}) \mathrm{Cl}](\mu-\mathrm{O})\left[\mathrm{MoTp} *(\mathrm{Cl}) \quad\left(\equiv \mathrm{NC}_{6} \mathrm{H}_{4} \mathrm{R}\right)\right] \quad(\mathrm{R}=\mathrm{OMe}$ and $\mathrm{NO}_{2}$ ) are given in Table 2. Both complexes exhibit the expected absorptions due to the $\mathrm{Tp}^{*}$ ligand ( $c a$. $2500 \mathrm{~cm}^{-1}$ due to $v_{(\mathrm{BH})}$ and $1400 \mathrm{~cm}^{-1}$ associated with the pyrazolyl ring). They possess bands characteristic of the terminal $\mathrm{Mo}=\mathrm{O}$ unit $\left(c a .960 \mathrm{~cm}^{-1}\right)$. This value was reported as $964 \mathrm{~cm}^{-1}$ for the starting material [Mo$\left.\mathrm{Tp}^{*}(\mathrm{O}) \mathrm{Cl}_{2}\right]$ [33]. For the compounds $\left[\mathrm{MoTp}(\mathrm{O}) \mathrm{Cl}_{2}\right]$ $(\mu-\mathrm{O})($ cis-isomer $)$ and $\left[\mathrm{MoTp}(\mathrm{O}) \mathrm{Cl}_{2}\right](\mu-\mathrm{O})($ trans-isomer), the peak at $958 \mathrm{~cm}^{-1}$ was assigned as $\mathrm{Mo}=\mathrm{O}$ of the terminal oxo groups [34].

The compound $[\mathrm{MoTp} *(\mathrm{O}) \mathrm{Cl}]_{2}(\mu-\mathrm{O})$ exhibited $v_{(\mathrm{Mo}=\mathrm{O})}$ at 960 and $859 \mathrm{~cm}^{-1}$. This value has been reported as 961 and $971 \mathrm{~cm}^{-1}$ for $\left[\mathrm{MoTp}^{\mathrm{pr}}(\mathrm{O}) \mathrm{Cl}\right](\mu-\mathrm{O})\left[\mathrm{MoTp}{ }^{\mathrm{pr}}(\mathrm{O})(\mathrm{OH})\right]$ $\left[\mathrm{Tp}^{\mathrm{pr}}=\right.$ hydrotris-(3-isopropylpyrazolyl)borate] [35]. The

Table 1. Characterization data for the new complexes

\begin{tabular}{lllllll}
\hline Complex & \multirow{2}{*}{ Colour } & \multirow{2}{*}{ Yield $(\%)$} & \multicolumn{2}{l}{ Elemental analytical data (calcd) (\%) } & & FAB-MS \\
\hline$(1)$ & & $\mathrm{C}$ & $\mathrm{H}$ & $\mathrm{N}$ & $17.0(18.0)$ & 1012.1 \\
$(2)$ & dark red & 51 & $44.0(44.1)$ & $4.9(5.1)$ & $18.35(19.1)$ & 1029.5 \\
\hline
\end{tabular}




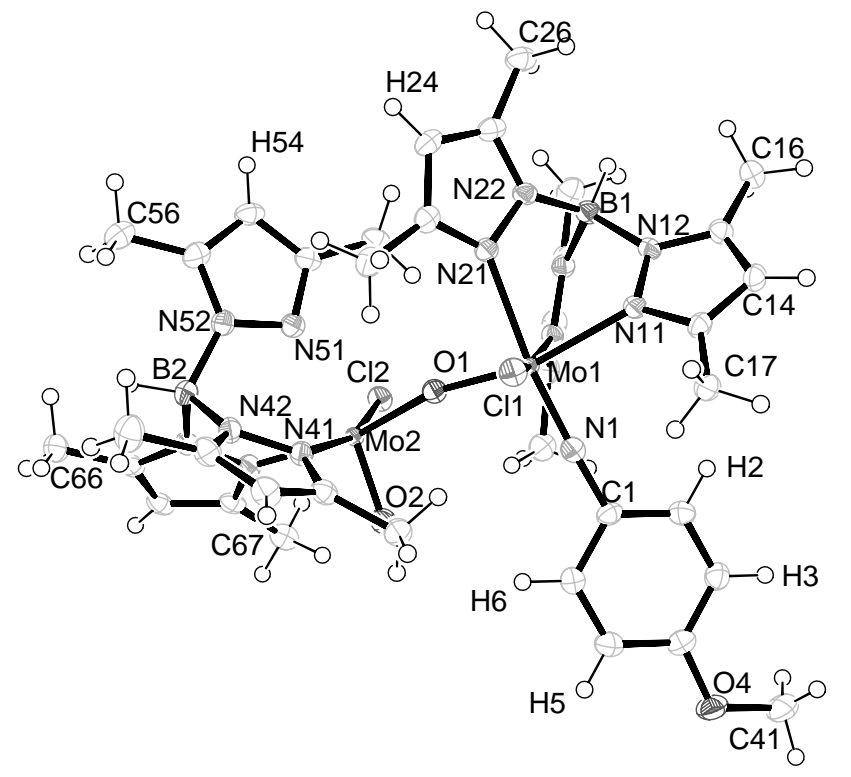

Figure 1. Molecular structure of the compound $[\mathrm{MoTp} *(\mathrm{O}) \mathrm{Cl}]$ $(\mu-\mathrm{O})\left[\mathrm{MoTp} *(\mathrm{Cl})\left(\equiv \mathrm{NC}_{6} \mathrm{H}_{4} \mathrm{OMe}\right)\right]$.

Table 2. I.r. data for the new complexes

\begin{tabular}{lllll}
\hline Complex & $v_{\mathrm{BH}}$ & $v_{\mathrm{Mo}=\mathrm{O}}$ & $v_{\mathrm{Mo} \equiv \mathrm{N}}$ & $v_{\mathrm{Mo}-\mathrm{O}-\mathrm{Mo}}$ \\
\hline$(1)$ & 2548 & 957 & 1205 & 788 \\
$(2)$ & 2546 & 961 & 1211 & 765 \\
\hline
\end{tabular}

i.r. spectrum of the mixed valence compound, $\left[\mathrm{Mo}^{\mathrm{V}} \mathrm{Tp}^{*} \mathrm{O}_{2}\right](\mu-\mathrm{O})\left[\mathrm{Mo}^{\mathrm{VI}} \mathrm{Tp} *(\mathrm{O}) \mathrm{Cl}\right]$ exhibited three $v_{(\mathrm{Mo}=\mathrm{O})}$ bands in the $850-1000 \mathrm{~cm}^{-1}$ region. The $v_{(\mathrm{Mo}=\mathrm{O})}$ bands were assigned to $\mathrm{Mo}^{\mathrm{V}}=\mathrm{O}\left(955 \mathrm{~cm}^{-1}\right)$ and cis- $\mathrm{Mo}^{\mathrm{VI}} \mathrm{O}_{2}\left(925,895 \mathrm{~cm}^{-1}\right)$ [36]. A detailed i.r. and Raman spectroscopy study was carried out for the geometric isomers (cis and trans) of $\left[\mathrm{MoTp}(\mathrm{O}) \mathrm{Cl}_{2}\right](\mu-\mathrm{O})$ [34]. According to this study, the peaks at 784 and $456 \mathrm{~cm}^{-1}$ were assigned to the asymmetric stretch and the deformation mode of the linear oxo-bridged unit, respectively [37]. For the compound $\left[\mathrm{MoTp}^{*}(\mathrm{O}) \mathrm{Cl}\right]_{2}(\mu-\mathrm{O})$, a symmetric stretch oxo-bridged unit was reported as $753 \mathrm{~cm}^{-1}$ [34]. Therefore, the peaks observed for the new compounds $\left[\mathrm{MoTp}^{*}(\mathrm{O}) \mathrm{Cl}\right](\mu-\mathrm{O})[\mathrm{MoTp} *(\mathrm{Cl})$ $\left.\left(\equiv \mathrm{NC}_{6} \mathrm{H}_{4} \mathrm{R}\right)\right]\left(\mathrm{R}=\mathrm{OMe}, \mathrm{NO}_{2}\right)$ at $c a .755$ and $455 \mathrm{~cm}^{-1}$ could be assigned to an asymmetric stretch and deformation mode of the $\mathrm{Mo}-\mathrm{O}-\mathrm{Mo}$ unit, respectively. The presence of the $\mu$-oxo ligand was indicated by a strong, broad $v_{\text {as }}(\mathrm{Mo}-\mathrm{O}-\mathrm{Mo})$ band at $750 \mathrm{~cm}^{-1}$ for the compound $\left[\mathrm{Mo}^{\mathrm{V}} \mathrm{Tp}^{*} \mathrm{O}_{2}\right](\mu-\mathrm{O})\left[\mathrm{Mo}{ }^{\mathrm{VI}} \mathrm{Tp}^{*}(\mathrm{O}) \mathrm{Cl}\right][36]$ as well.

The two vibrations at $c a .3370$ and $3450 \mathrm{~cm}^{-1}$ from the symmetric and asymmetric stretching modes of the $\mathrm{NH}_{2}$ groups of the free ligands have completely disappeared in the i.r. spectra of all the new complexes. Indeed, the structure determined for the compound $[\mathrm{MoTp} *(\mathrm{O}) \mathrm{Cl}](\mu-\mathrm{O})\left[\mathrm{MoTp} *(\mathrm{Cl})\left(\equiv \mathrm{NC}_{6} \mathrm{H}_{4} \mathrm{OMe}\right)\right]$ by $\mathrm{X}$-ray diffraction analyses revealed a triple bond between molybdenum and nitrogen. In general, identifying a $v_{(\mathrm{Mo}=\mathrm{N})}$ or $v_{(\mathrm{Mo} \equiv \mathrm{N})}$ vibration is a difficult task because of: (i) the variability in the $\mathrm{Mo}-\mathrm{N}$ bond order, and (ii) coupling of the $\mathrm{Mo}=\mathrm{N}$ vibration to other vibrations in the molecule, in particular the adjacent $\mathrm{N}-\mathrm{C}$ vibration of the imido group [10]. However, a value of $1100-1300 \mathrm{~cm}^{-1}$ for the $v_{(\mathrm{Mo}=\mathrm{N})}$ has been suggested [38] and McCleverty et al. [17] reported values in the $1200-1250 \mathrm{~cm}^{-1}$ range for the compounds $[\mathrm{MoTp} *(\mathrm{O}) \mathrm{Cl}(=\mathrm{NR})]\left(\mathrm{R}=4\right.$-tolyl, and $\left.\mathrm{C}_{6} \mathrm{H}_{4} \mathrm{NMe}_{2}-4\right)$. The i.r. spectra of the oxo-bridged oxo(arylimido) molybdenum(V) compounds, [MoTp*(O)Cl] $(\mu-\mathrm{O})[\mathrm{MoTp} *$ $\left.(\mathrm{Cl})\left(\equiv \mathrm{NC}_{6} \mathrm{H}_{4} \mathrm{R}\right)\right],\left(\mathrm{R}=\mathrm{OMe}, \mathrm{NO}_{2}\right)$ also exhibited peaks around $1200-1300 \mathrm{~cm}^{-1}$ range which may be ascribed to $\left.v_{(\mathrm{Mo}} \equiv \mathrm{N}\right)$.

The ${ }^{1} \mathrm{H}$-n.m.r. data (Table 3 ) of the new complexes $\left[\mathrm{MoTp}^{*}(\mathrm{O}) \mathrm{Cl}\right](\mu-\mathrm{O})\left[\mathrm{MoTp} *(\mathrm{Cl})\left(\equiv \mathrm{NC}_{6} \mathrm{H}_{4} \mathrm{R}\right)\right](\mathrm{R}=\mathrm{OMe}$, $\mathrm{NO}_{2}$ ) exhibited all the expected peaks. The four $\mathrm{C}_{6} \mathrm{H}_{4}$ protons are clearly split into two sets of two (implying the equivalance of $\mathrm{H}^{2}$ with $\mathrm{H}^{6}$, and $\mathrm{H}^{3}$ with $\mathrm{H}^{5}$, by free rotation of the phenyl ring with respect to the metal core). The signals attributable to the $\mathrm{Tp}^{*}$ ligand appeared as two groups of singlets in the region 1.233.56 p.p.m. assigned to the pyrazolyl ring methyl protons and 5.28-6.21 p.p.m. due to the pyrazolyl ring $\mathrm{C}-\mathrm{H}$ protons. The low symmetry of both compounds means that all three pyrazol $\mathrm{H}(4)$ protons and all six methyl groups of the Tp* ligand are non-equivalent. For $\left[\mathrm{MoTp}^{*}(\mathrm{O}) \mathrm{Cl}\right](\mu-\mathrm{O})\left[\mathrm{MoTp} *(\mathrm{Cl})\left(\equiv \mathrm{NC}_{6} \mathrm{H}_{4} \mathrm{OMe}\right)\right]$ six pyr-

Table 3. ${ }^{1} \mathrm{H}-\mathrm{n} . \mathrm{m} . \mathrm{r}$. data for the new complexes $(400 \mathrm{MHz}, 293 \mathrm{~K}$, $\mathrm{CDCl}_{3}$ )

\begin{tabular}{|c|c|c|}
\hline Complex & $\delta_{\mathrm{H}}(A)^{\mathrm{a}}$ & Multiplicity and assignments \\
\hline \multirow[t]{15}{*}{ (1) } & 7.53 & $\left(\mathrm{~d}, 2 \mathrm{H}, \mathrm{J}(\mathrm{HH}) 8, \mathrm{C}_{6} \mathrm{H}_{4} \mathrm{OMe}\right)$ \\
\hline & 6.77 & $\left(\mathrm{~d}, 2 \mathrm{H}, \mathrm{J}(\mathrm{HH}) 8, \mathrm{C}_{6} \mathrm{H}_{4} \mathrm{OMe}\right)$ \\
\hline & 6.04 & $\left(\mathrm{~s}, 1 \mathrm{H}, \mathrm{Me}_{2} \mathrm{C}_{3} H \mathrm{~N}_{2}\right)$ \\
\hline & 5.94 & $\left(\mathrm{~s}, 1 \mathrm{H}, \mathrm{Me}_{2} \mathrm{C}_{3} H \mathrm{~N}_{2}\right)$ \\
\hline & 5.82 & $\left(\mathrm{~s}, 1 \mathrm{H}, \mathrm{Me}_{2} \mathrm{C}_{3} H \mathrm{~N}_{2}\right)$ \\
\hline & 5.79 & $\left(\mathrm{~s}, 1 \mathrm{H}, \mathrm{Me}_{2} \mathrm{C}_{3} H \mathrm{~N}_{2}\right)$ \\
\hline & 5.41 & $\left(\mathrm{~s}, 1 \mathrm{H}, \mathrm{Me}_{2} \mathrm{C}_{3} H \mathrm{~N}_{2}\right)$ \\
\hline & 5.36 & $\left(\mathrm{~s}, 1 \mathrm{H}, \mathrm{Me}_{2} \mathrm{C}_{3} H \mathrm{~N}_{2}\right)$ \\
\hline & 3.83 & $\left(\mathrm{~s}, 3 \mathrm{H}, \mathrm{OCH}_{3}\right)$ \\
\hline & 3.20 & $\left(\mathrm{~s}, 6 \mathrm{H}, \mathrm{Me}_{2} \mathrm{C}_{3} \mathrm{HN}_{2}\right)$ \\
\hline & 2.79 & $\left(\mathrm{~s}, 6 \mathrm{H}, \mathrm{Me}_{2} \mathrm{C}_{3} \mathrm{HN}_{2}\right)$ \\
\hline & 2.71 & $\left(\mathrm{~s}, 6 \mathrm{H}, \mathrm{Me}_{2} \mathrm{C}_{3} \mathrm{HN}_{2}\right)$ \\
\hline & 2.48 & $\left(\mathrm{~s}, 6 \mathrm{H}, \mathrm{Me}_{2} \mathrm{C}_{3} \mathrm{HN}_{2}\right)$ \\
\hline & 2.37 & $\left(\mathrm{~s}, 6 \mathrm{H}, \mathrm{Me}_{2} \mathrm{C}_{3} \mathrm{HN}_{2}\right)$ \\
\hline & 2.30 & $\left(\mathrm{~s}, 6 \mathrm{H}, \mathrm{Me}_{2} \mathrm{C}_{3} \mathrm{HN}_{2}\right)$ \\
\hline \multirow[t]{11}{*}{ (2) } & 8.12 & $\left(\mathrm{~d}, 2 \mathrm{H}, \mathrm{J}(\mathrm{HH}) 9, \mathrm{C}_{6} \mathrm{H}_{4} \mathrm{NO}_{2}\right)$ \\
\hline & 6.90 & $\left(\mathrm{~d}, 2 \mathrm{H}, \mathrm{J}(\mathrm{HH}) 9, \mathrm{C}_{6} \mathrm{H}_{4} \mathrm{NO}_{2}\right)$ \\
\hline & 5.85 & $\left(\mathrm{~s}, 2 \mathrm{H}, \mathrm{Me}_{2} \mathrm{C}_{3} H \mathrm{~N}_{2}\right)$ \\
\hline & 5.68 & $\left(\mathrm{~s}, 2 \mathrm{H}, \mathrm{Me}_{2} \mathrm{C}_{3} H \mathrm{~N}_{2}\right)$ \\
\hline & 5.57 & $\left(\mathrm{~s}, 2 \mathrm{H}, \mathrm{Me}_{2} \mathrm{C}_{3} H \mathrm{~N}_{2}\right)$ \\
\hline & 2.71 & $\left(\mathrm{~s}, 6 \mathrm{H}, \mathrm{Me}_{2} \mathrm{C}_{3} \mathrm{HN}_{2}\right)$ \\
\hline & 2.37 & $\left(\mathrm{~s}, 6 \mathrm{H}, \mathrm{Me}_{2} \mathrm{C}_{3} \mathrm{HN}_{2}\right)$ \\
\hline & 2.34 & $\left(\mathrm{~s}, 6 \mathrm{H}, \mathrm{Me}_{2} \mathrm{C}_{3} \mathrm{HN}_{2}\right)$ \\
\hline & 2.32 & $\left(\mathrm{~s}, 6 \mathrm{H}, \mathrm{Me}_{2} \mathrm{C}_{3} \mathrm{HN}_{2}\right)$ \\
\hline & 2.29 & $\left(\mathrm{~s}, 6 \mathrm{H}, \mathrm{Me}_{2} \mathrm{C}_{3} \mathrm{HN}_{2}\right)$ \\
\hline & 2.11 & $\left(\mathrm{~s}, 6 \mathrm{H}, \mathrm{Me}_{2} \mathrm{C}_{3} \mathrm{HN}_{2}\right)$ \\
\hline
\end{tabular}

${ }^{\mathrm{a}}$ In $\mathrm{CDCl}_{3} ; A=$ relative intensity; ${ }^{\mathrm{b}} J$ values in $\mathrm{Hz}$. 
Table 4. Crystal data and structure refinement for $[\mathrm{MoTp} *(\mathrm{O}) \mathrm{Cl}]$ $(\mu-\mathrm{O})\left[\mathrm{MoTp} *(\mathrm{Cl})\left(\equiv \mathrm{NC}_{6} \mathrm{H}_{4} \mathrm{OMe}\right)\right]$

\begin{tabular}{|c|c|}
\hline Empirical formula & $\mathrm{C}_{37} \mathrm{H}_{51} \mathrm{~B}_{2} \mathrm{Cl}_{2} \mathrm{Mo}_{2} \mathrm{~N}_{13} \mathrm{O}_{3}$ \\
\hline Formula weight & 1010.31 \\
\hline Temperature & $100(2) \mathrm{K}$ \\
\hline Wavelength & $1.54184 \AA$ \\
\hline Crystal system & Triclinic \\
\hline Space group & P-1 \\
\hline \multicolumn{2}{|l|}{ Unit cell dimensions } \\
\hline$a$ & $11.0200(2) \AA$ \\
\hline$b$ & $11.5868(2)$ \\
\hline$c$ & 18.7414(3) A \\
\hline$\alpha$ & $77.3320(10)^{\circ}$ \\
\hline$\beta$ & $76.8440(10)^{\circ}$ \\
\hline$\gamma$ & $75.8450(10)^{\circ}$ \\
\hline Volume & $2225.27(7) \AA^{3}$ \\
\hline$Z$ & 2 \\
\hline Density (calculated) & $1.508 \mathrm{mg} \mathrm{m}^{-3}$ \\
\hline Absorption coefficient & $0.735 \mathrm{~mm}^{-1}$ \\
\hline$F\left(\begin{array}{llll}0 & 0 & 0\end{array}\right)$ & 1032 \\
\hline Crystal size & $0.08 \times 0.08 \times 0.03 \mathrm{~mm}$ \\
\hline$\theta$ range for data collection & $1.13-25.70^{\circ}$ \\
\hline Index ranges & $\begin{array}{l}-13 \leq h \leq 12,-13 \leq k \leq 14 \\
-22 \leq l \leq 20\end{array}$ \\
\hline Reflections collected & 15997 \\
\hline Independent reflections & $7504\left[R_{\mathrm{int}}=0.0226\right]$ \\
\hline Completeness to $\theta=25.70^{\circ}$ & $88.7 \%$ \\
\hline Refinement method & Full-matrix least-squares on $F^{2}$ \\
\hline Data/restraints/parameters & $7504 / 0 / 553$ \\
\hline Goodness-of-fit on $F^{2}$ & $S=0.924$ \\
\hline $\begin{array}{l}R \text { indices [for } 6435 \text { reflections } \\
\text { with } I>2(\mathrm{I}) \text { ] }\end{array}$ & $R_{1}=0.0227, w R_{2}=0.0533$ \\
\hline$R$ indices (for all 7504 data) & $R_{1}=0.0267, w R_{2}=0.0540$ \\
\hline Weighting scheme & $\begin{array}{l}w^{-1}=\sigma^{2}\left(F_{0}^{2}\right)+(a P)^{2}+(b P), \\
\text { where } P=\left[\max \left(F_{0}^{2}, 0\right)+2 F_{\mathrm{c}}^{2}\right] / 3 \\
a=0.0316, b=0.0000\end{array}$ \\
\hline Largest diff. peak and hole & 0.375 and $-0.489 \mathrm{e}^{-3}$ \\
\hline
\end{tabular}

azol $\mathrm{H}(4)$ signals were observed in the range $\delta 6.04-5.36$ due to the two non-equivalent $\mathrm{Tp}^{*}$ ligand, whereas in the spectrum of $[\mathrm{MoTp} *(\mathrm{O}) \mathrm{Cl}](\mu-\mathrm{O})[\mathrm{MoTp} *(\mathrm{Cl})$ $\left.\left(\equiv \mathrm{NC}_{6} \mathrm{H}_{4} \mathrm{NO}_{2}\right)\right]$ three signals were observed. The reason for observing three resonances instead of six in $[\mathrm{MoTp} *(\mathrm{O}) \mathrm{Cl}](\mu-\mathrm{O})\left[\mathrm{MoTp} *(\mathrm{Cl})\left(\equiv \mathrm{NC}_{6} \mathrm{H}_{4} \mathrm{NO}_{2}\right)\right] \quad$ could be attributed to accidental degeneracy of the three $\mathrm{H}(4)$ resonances in two non-equivalent $\mathrm{Tp}^{*}$ ligands. This effect has previously been observed by McCleverty et al. [39, 40]. The low symmetry of these compounds also means six methyl resonances for each $\mathrm{Tp}^{*}$ ligand must be observed in the area of 1.5-3.5 p.p.m. Indeed, six resonances attributible to the metyl groups of $\mathrm{Tp}^{*}$ ligand were observed for the compounds [MoT$\left.\mathrm{p}^{*}(\mathrm{O}) \mathrm{Cl}\right](\mu-\mathrm{O})\left[\mathrm{MoTp} *(\mathrm{Cl})\left(\equiv \mathrm{NC}_{6} \mathrm{H}_{4} \mathrm{OMe}\right)\right.$ and $[\mathrm{MoTp} *$ $(\mathrm{O})-\mathrm{Cl}](\mu-\mathrm{O})\left[\mathrm{MoTp} *(\mathrm{Cl})\left(\equiv \mathrm{NC}_{6} \mathrm{H}_{4} \mathrm{NO}_{2}\right)\right]$ in the region $\delta$ $3.20-2.30$ and 2.71-2.11 respectively. The observation of only six resonances (total integrated area equivalent to 12 protons) instead of 12 could also be attributed to accidental degeneracy of six methyl resonances of two inequivalent $\mathrm{Tp}^{*}$ ligands.

Generally $\mathrm{NH}_{2}$ and $\mathrm{NH}$ protons appear in the $\delta$ 11.14-13.15 p.p.m. range [10]. No broad signals typical of amine or amide protons were observed in the
Table 5. Selected bond lengths $(\AA)$ and angles $\left(^{\circ}\right)$ for $\left[\mathrm{MoTp}^{*}(\mathrm{O}) \mathrm{Cl}\right]$ $\left(\mu\right.$-O) $\left[\mathrm{MoTp} *(\mathrm{Cl})\left(\equiv \mathrm{NC}_{6} \mathrm{H}_{4} \mathrm{OMe}\right)\right]$

\begin{tabular}{lc}
\hline Bond lengths & \\
$\mathrm{Mo}(1)-\mathrm{N}(1)$ & $1.7391(19)$ \\
$\mathrm{Mo}(1)-\mathrm{O}(1)$ & $1.9004(14)$ \\
$\mathrm{Mo}(1)-\mathrm{Cl}(1)$ & $2.4159(5)$ \\
$\mathrm{O}(1)-\mathrm{Mo}(2)$ & $1.8731(14)$ \\
$\mathrm{N}(1)-\mathrm{C}(1)$ & $1.381(3)$ \\
$\mathrm{Mo}(2)-\mathrm{O}(2)$ & $1.6779(16)$ \\
$\mathrm{Mo}(2)-\mathrm{Cl}(2)$ & $2.3918(5)$ \\
$\mathrm{B}(1)-\mathrm{N}(22)$ & $1.522(3)$ \\
$\mathrm{B}(1)-\mathrm{N}(12)$ & $1.544(3)$ \\
$\mathrm{B}(1)-\mathrm{N}(32)$ & $1.546(3)$ \\
$\mathrm{B}(2)-\mathrm{N}(52)$ & $1.525(3)$ \\
$\mathrm{B}(2)-\mathrm{N}(42)$ & $1.547(3)$ \\
$\mathrm{B}(2)-\mathrm{N}(62)$ & $1.546(3)$ \\
$\mathrm{Mo}(1)-\mathrm{N}(11)$ & $2.2185(17)$ \\
$\mathrm{Mo}(1)-\mathrm{N}(21)$ & $2.2768(18)$ \\
$\mathrm{Mo}(1)-\mathrm{Cl}(1)$ & $2.4159(5)$ \\
$\mathrm{Mo}(2)-\mathrm{N}(41)$ & $2.1600(18)$ \\
$\mathrm{Mo}(2)-\mathrm{N}(61)$ & $2.2180(17)$ \\
$\mathrm{Mo}(2)-\mathrm{N}(51)$ & $2.3811(18)$ \\
Bond angles & \\
$\mathrm{Mo}(2)-\mathrm{O}(1)-\mathrm{Mo}(1)$ & $164.99(9)$ \\
$\mathrm{C}(1)-\mathrm{N}(1)-\mathrm{Mo}(1)$ & $176.67(7)$ \\
$\mathrm{N}(1)-\mathrm{Mo}(1)-\mathrm{O}(1)$ & $100.16(7)$ \\
$\mathrm{N}(1)-\mathrm{Mo}(1)-\mathrm{N}(11)$ & $93.09(7)$ \\
$\mathrm{N}(1)-\mathrm{Mo}(1)-\mathrm{Cl}(1)$ & $97.03(6)$ \\
$\mathrm{O}(1)-\mathrm{Mo}(1)-\mathrm{Cl}(1)$ & $98.45(5)$ \\
$\mathrm{N}(11)-\mathrm{Mo}(1)-\mathrm{Cl}(1)$ & $88.19(5)$ \\
$\mathrm{O}(2)-\mathrm{Mo}(2)-\mathrm{O}(1)$ & $101.60(7)$ \\
$\mathrm{O}(1)-\mathrm{Mo}(2)-\mathrm{N}(41)$ & $92.23(7)$ \\
$\mathrm{O}(2)-\mathrm{Mo}(2)-\mathrm{Cl}(2)$ & $98.93(5)$ \\
$\mathrm{O}(1)-\mathrm{Mo}(2)-\mathrm{Cl}(2)$ & $95.32(5)$ \\
$\mathrm{N}(31)-\mathrm{Mo}(1)-\mathrm{N}(11)$ & $81.70(7)$ \\
$\mathrm{N}(41)-\mathrm{Mo}(2)-\mathrm{N}(61)$ & $82.96(7)$ \\
$\mathrm{O}(2)-\mathrm{Mo}(2)-\mathrm{N}(51)$ & $169.67(7)$ \\
$\mathrm{O}(1)-\mathrm{Mo}(2)-\mathrm{N}(51)$ & $88.30(6)$ \\
$\mathrm{N}(41)-\mathrm{Mo}(2)-\mathrm{N}(51)$ & $82.27(7)$ \\
$\mathrm{N}(61)-\mathrm{Mo}(2)-\mathrm{N}(51)$ & $78.69(6)$ \\
$\mathrm{O}(2)-\mathrm{Mo}(2)-\mathrm{N}(61)$ & $91.26(7)$ \\
$\mathrm{O}(1)-\mathrm{Mo}(2)-\mathrm{N}(61)$ & $166.60(7)$ \\
$\mathrm{N}(41)-\mathrm{Mo}(2)-\mathrm{N}(61)$ & \\
\hline & \\
\hline & \\
&
\end{tabular}

${ }^{1}$ H-n.m.r. spectra of the new compounds which leads us to believe that they are either $\mathrm{Mo}=\mathrm{N}$ or $\mathrm{Mo} \equiv \mathrm{N}$ linkages.

\section{Crystal structure determination and refinement}

A single crystal of $\left[\mathrm{MoTp}^{*}(\mathrm{O}) \mathrm{Cl}\right](\mu-\mathrm{O})[\mathrm{MoTp} *$ $\left.(\mathrm{Cl})\left(\equiv \mathrm{NC}_{6} \mathrm{H}_{4} \mathrm{OMe}\right)\right]$ was recrystallized from a $\mathrm{CH}_{2} \mathrm{Cl}_{2}$ / hexane mixture and coated in high-vacuum grease and mounted on a glass fibre. A view of the molecular structure of $[\mathrm{MoTp} *(\mathrm{O}) \mathrm{Cl}](\mu-\mathrm{O})[\mathrm{MoTp} *(\mathrm{Cl})$ $\left.\left(\equiv \mathrm{NC}_{6} \mathrm{H}_{4} \mathrm{OMe}\right)\right]$ along with the atomic labelling scheme is shown in Figure 1. X-ray measurements were made using a Bruker SMART CCD area-detector diffractometer with $\mathrm{Cu} K_{\alpha}$ radiation $(\lambda=1.54184 \AA)$ [41]. Intensities were integrated [42] from several series of exposures, each exposure covering $0.3^{\circ}$ in $\omega$, and the total data set being a sphere. Absorption corrections were applied, based on multiple and symmetry-equivalent measure- 
ments [43]. The structure was solved by Patterson synthesis and refined by least squares on weighted $F^{2}$ values for all reflections (Table 4) [44]. All non-hydrogen atoms were assigned anisotropic displacement parameters and refined without positional constraints. Hydrogen atoms $\mathrm{H}(1 \mathrm{~A}), \mathrm{H}(2 \mathrm{~A})$ were located in the electron density difference map, assigned isotropic displacement parameters and refined without positional constraints. All other hydrogen atoms were constrained to ideal geometries and refined with fixed isotropic displacement parameters. Refinement proceeded smoothly to give the residuals shown in Table 4. Complex neutral-atom scattering factors were used [45].

Crystal structure of $\left[\mathrm{MoTp}^{*}(\mathrm{O}) \mathrm{Cl}\right](\mu-\mathrm{O})\left[\mathrm{MoTp}^{*}(\mathrm{Cl})\right.$ ( $\equiv \mathrm{NC}_{6} \mathrm{H}_{4} \mathrm{OMe}$ )]

The compound $[\mathrm{MoTp} *(\mathrm{O}) \mathrm{Cl}](\mu-\mathrm{O})[\mathrm{MoTp} *(\mathrm{Cl})$ $\left.\left(\equiv \mathrm{NC}_{6} \mathrm{H}_{4} \mathrm{OMe}\right)\right]$ is comprised of two unidentical MoTp* $\mathrm{Cl}$ unit connected by a single oxo-bridge. There are two pseudo-octahedral metal centers with three nitrogen atoms of the Tp* ligand occupying one face of the octahedron (Figure 1).

$\mathrm{Mo}(2)$ is coordinated by facial $\mathrm{Tp}^{*}$, terminal oxo, chloro and bridging oxo ligands whereas the $\operatorname{Mo}(1)$ is coordinated by facial $\mathrm{Tp}^{*}$, chloro, arylimido and a bridging oxo ligand. The two chloride atoms were trans to each other. Atomic co-ordinates and selected bond distances and bond angles are given in Table 5. The $\mathrm{Mo}(1)-\mathrm{O}(1), \mathrm{Mo}(2)-\mathrm{O}(1), \mathrm{Mo}(2)-\mathrm{O}(2), \mathrm{Mo}(1)-\mathrm{Cl}(1)$, $\mathrm{Mo}(2)-\mathrm{Cl}(2)$, distances of 1.9004(14), 1.8731(14),
1.6779(16), 2.4159(5), 2.3918(5), $1 \AA$, respectively, are all within respected ranges [37]. The $\mathrm{Mo}(1)-(\mu-\mathrm{O})$ distance was reported [46] as 1.8886(9) $\AA$ in [\{MoT$\left.\mathrm{p}^{*}(\mathrm{O}) \mathrm{Cl}_{\}_{2}}\right](\mu-\mathrm{O})$. The X-ray crystal structures of two geometric isomers of the related complex [MoTp*$(\mathrm{O})-\mathrm{Cl}]_{2}(\mu-\mathrm{O}) \quad(\mathrm{Tp}=$ hydrotrispyrazolborate $)$ were reported by Lincoln and Koch. The reported bond distances are comparable to those encountered here. For instance, in the trans isomer, the $\mathrm{Mo}(1)-(\mu-\mathrm{O})$ distances of 1.861(1) $\AA$ is reported [34] which is comparable to the above value for $\left.\operatorname{MoTp}^{*}(\mathrm{O}) \mathrm{Cl}\right](\mu-\mathrm{O})$ $\left[\mathrm{MoTp} *(\mathrm{Cl})\left(\equiv \mathrm{NC}_{6} \mathrm{H}_{4} \mathrm{OMe}\right)\right]$.

For $[\mathrm{MoTp} *(\mathrm{O}) \mathrm{Cl}](\mu-\mathrm{O})\left[\mathrm{MoTp} *(\mathrm{Cl})\left(\equiv \mathrm{NC}_{6} \mathrm{H}_{4} \mathrm{OMe}\right)\right]$, deviations from octahedral geometry are manifest in the bond angles $\mathrm{O}(2)-\mathrm{Mo}(2)-\mathrm{O}(1) \quad\left(101.60(7)^{\circ}\right)$ and $\mathrm{O}(1)-\mathrm{Mo}(1)-\mathrm{N}(11)\left(164.28(7)^{\circ}\right)$. These values are in accord with the data reported for $\left[\mathrm{MoTp}^{*} \mathrm{OCl}\right]_{2}(\mu-\mathrm{O})$ and $\left[\mathrm{MoTp}{ }^{\mathrm{Pr} O C l}\right](\mu-\mathrm{O})\left[\mathrm{MoTp}{ }^{\mathrm{Pr}} \mathrm{O}(\mathrm{OH})\right] \quad[35]$. The $\mathrm{Mo}(1)-\mathrm{O}(1)-\mathrm{Mo}(2)$ angle of $164.99(9)^{\circ}$ deviates considerably from linearity (cf. 177.4(4) ${ }^{\circ}$ for (cis) [MoTp*(O)-Cl $]_{2}(\mu-\mathrm{O})$ and $177.3(2)^{\circ}$ and $180^{\circ}$ for (trans) [MoT$\mathrm{p}(\mathrm{O}) \mathrm{Cl}_{2}(\mu-\mathrm{O})$ [34]. This value is comparable to the one $\left(158.5(2)^{\circ}\right)$ reported (36) for the compound $\left[\mathrm{MoTp}{ }^{\mathrm{Pr}}\right.$ $\mathrm{OCl}](\mu-\mathrm{O})\left[\mathrm{MoTp}{ }^{\mathrm{Pr}} \mathrm{O}(\mathrm{OH})\right]$ 176.67(17).

Molybdenum nitrogen multiple bond could either be a double bond with $\mathrm{Mo}-\mathrm{N}-\mathrm{C}$ angle of $120^{\circ}$ or a triple bond with $\mathrm{Mo}-\mathrm{N}-\mathrm{C}$ angle of $180^{\circ}$. In the first case imido group acts as a four electron donor with no lone pair in the latter case it behaves as a six electron donor. The $\mathrm{Mo}(1)-\mathrm{N}(1)-\mathrm{C}(1)$ bond angle of $176.67(17)^{\circ}$ for $[\mathrm{MoT}-$ $\left.\mathrm{p}^{*}(\mathrm{O}) \mathrm{Cl}\right](\mu-\mathrm{O})\left[\mathrm{MoTp} *(\mathrm{Cl})\left(\equiv \mathrm{NC}_{6} \mathrm{H}_{4} \mathrm{OMe}\right)\right]$ is indicative

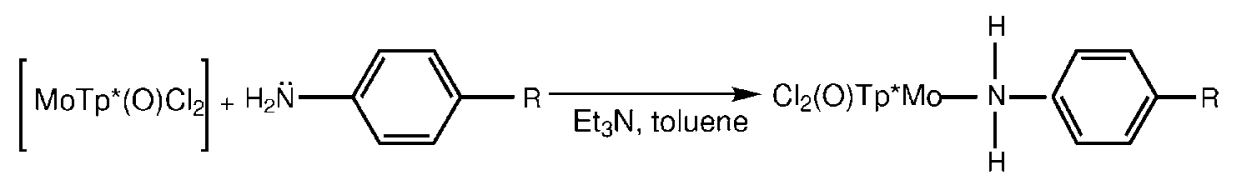

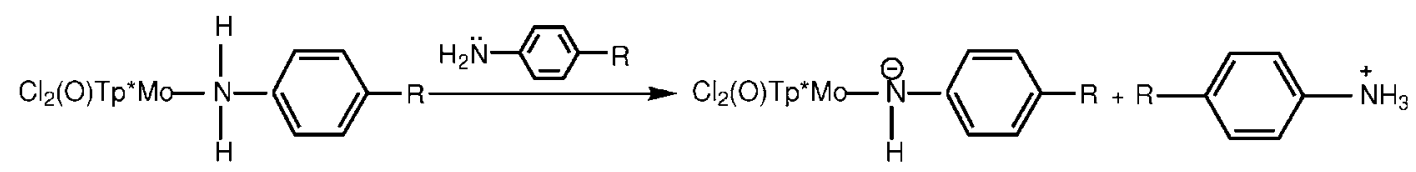

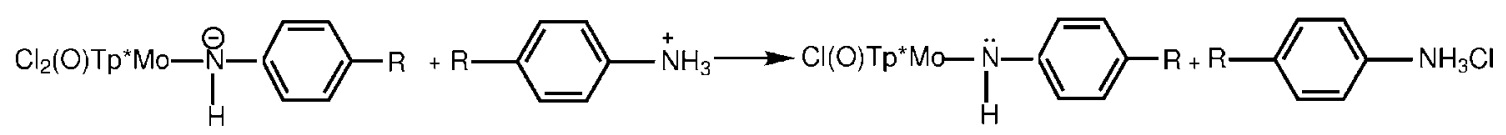<smiles></smiles><smiles>CCPc1ccc(N=[W][O-])cc1</smiles> 
of a linear $\mathrm{Mo}-\mathrm{N}-\mathrm{C}$ (aryl) unit. The typical range for this arrangement was reported as $160-180^{\circ}$ [38]. Mo(1)-N(1) bond length of 1.7391(19) $\AA$ is also indicative of a $\mathrm{Mo} \equiv \mathrm{N}$ bond. This value is in accord with the reported bond length values for compounds containing $\mathrm{Mo} \equiv \mathrm{N}$ bond and shorter than the $\mathrm{Mo}=\mathrm{N}$ ones [38].

In conclusion, complexes $\left[\mathrm{MoTp}^{*}(\mathrm{O}) \mathrm{Cl}\right](\mu-\mathrm{O})$ $\left[\mathrm{MoTp} *(\mathrm{Cl})\left(\equiv \mathrm{NC}_{6} \mathrm{H}_{4} \mathrm{R}\right)\right] \quad\left(\mathrm{R}=\mathrm{OMe}, \quad \mathrm{NO}_{2}\right) \quad$ described herein are one of the rare examples of a family of oxobridged oxo(arylimido) $\mathrm{Mo}(\mathrm{V})$ complexes containing tris(pyrazol)borate co-ligand.

\section{Acknowledgements}

We thank the TUBITAK, Research Council of Turkey, for financial support and Prof. J. A. McCleverty for providing the $\mathrm{Tp}^{*}$ (hydrotris(3,5-dimethylpyrazol-1yl)borate) ligand.

\section{Supplementary material}

Crystallographic data for the structural analysis have been deposited with the Cambridge Crystallographic Data Centre, CCDC, No. 234654.

\section{References}

1. S. Trofimenko, J. Am. Chem. Soc., 89, 3170 (1967).

2. S. Trofimenko, J.P. Jesson and D.R. Eaton, J. Am. Chem. Soc., 89, 3148 (1967)

3. M.D. Ward, J.A. McCleverty and J.C. Jeffery, Coord. Chem. Rev., 222, 251 (2001)

4. J.H. Enemark and K.B. Swedo, J. Chem. Education, 56(2), 70 (1979).

5. D.L. Reger, S.S. Mason and A.L. Rheingold, Inorg. Chem., 32, 5216 (1993)

6. M.S. Sanford, L.M. Henling and R.H. Grubbs, Organometallics, 17, 5384 (1998).

7. S. Trofimenko, Scorpionates - The Coordination Chemistry of Polypyrazolyl-borate Ligands, Imperial College Press, London, 1999.

8. C.D. Garner and C.M. Charnock, in G. Wilkinson, R.D. Gilliard and J.A. McCleverty (eds.) Comprehensive Coordination Chemistry, Pergamon Press, Oxford, 1987, p. 1323.

9. D. Sellmann, B. Hadawi, F. Knoch and M. Moll, Inorg. Chem., 34, 5963 (1995)

10. D.E. Wigley, Progr. Inorg. Chem., 42, 239 (1994).

11. V.C. Gibson, C. Redshaw, G.L.P. Walker, W. Clegg and M.R.J. Elsegood, J. Organomet. Chem., 689, 332, (2004).

12. H.Y. Cho, Soo-G. Roh and J.H. Jeong, Polyhedron, 21, 1211 (2002).

13. K.A. Rufanov, D.N. Zarubin, N.A. Ustynyuk, D.N. Gourevitch, J. Sundermeyer, A.V. Churakov and J.A.K. Howard, Polyhedron, 20, 379 (2001).

14. H.H. Fox, K.B. Yap, J. Robbins, S. Cai and R.R. Schrock, Inorg. Chem., 31, 2281 (1992).
15. M.C.W. Chan, F.W. Lee, K. Heung and C.M. Che, J. Chem. Soc., Dalton Trans., 3197 (1999).

16. E.I. Stiefel, in G. Wilkinson, R.D. Gillard and J.A. McCleverty, (eds.) Comprehensive Coordination Chemistry, 1987, p. 1375.

17. S.M. Lee, R. Kowallick, M. Marcaccio, J.A. McCleverty and M.D. Ward, J. Chem. Soc., Dalton Trans., 3443 (1998).

18. W. Klaui and T. Hardt, J. Organomet. Chem., 553, 241 (1998).

19. G.R. Clark, A.J. Nielson and C.E. Rickard, J. Chem. Soc. Dalton Trans., 4265 (1996).

20. R.C.B. Copley, P.W. Dyer, V. Gibson, J.A.K. Howard and B. Whittle, Polyhedron, 15, 3001 (1996).

21. W.M. Vaughan, K.A. Abboud and J.M. Boncella, J. Organomet. Chem., 127, 1201 (1994).

22. T.A. Coffey, G.D. Forster and G. Hogarth, J. Chem. Soc., Dalton Trans., 2337 (1995).

23. A.A. Danopoulos, G. Wilkinson, B. Hussain-Bates and M.B. Hursthouse, J. Chem. Soc., Dalton Trans., 269 (1991).

24. A.A. Danopoulos, G. Wilkinson, T.K.N. Sweet and M.B. Hursthouse, Polyhedron 15, 873 (1996).

25. V. Saboonchian, A.A. Danopoulos, A. Gutierrez, G. Wilkinson and D.J. Williams, Polyhedron, 10, 2241 (1991).

26. A.A. Danopoulos, G. Wilkinson and D.J. Williams, J. Chem. Soc., Chem. Commun., 181 (1991).

27. H.W. Lam, G. Wilkinson and D.J. Williams, Polyhedron, 10, 2647 (1991).

28. V.C. Gibson, C. Redshaw, G.L.P. Walker, W. Clegg and M.R.J. Elsegood, J. Organomet. Chem., 689, 332 (2004).

29. J.B. Strong, B.S. Haggerty, A.L. Rheinhold and E.A. Maatta, Chem. Commun. 1137 (1997).

30. V.C. Gibson, A.J. Graham, D.L. Ormsby, B.P. Ward, A.J.P. White and D.J. Williams, J. Chem. Soc., Dalton Trans., 2597 (2002).

31. V.C. Gibson, C. Redshaw, W. Clegg, M.R.j. Elsegood, U. Siemeling and T. Turk, Polyhedron, 23, 189 (2004).

32. H.Y. Cho, S.-G. Roh and J.H. Jeong, Polyhedron, 21, 1211 (2002).

33. S.A. Roberts, C.G. Young, C.A. Kippe, Jr. W.E. Cleland, K. Yamanouchi, M.D. Carducci and J.H. Enemark, Inorg. Chem., 29, 3650 (1990).

34. S. Lincoln and S.A. Koch, Inorg. Chem., 25, 1594 (1986).

35. A. Miller, C. Doonan, L. Laughlin and C. Young, Inorg. Chim. Acta, 337, 393 (2002).

36. A. Eagle, F. Mackoy and G. Young, Inorg. Chem., 30, 1425 (1991).

37. S. Lincoln and T.M. Loehr, Abstracts of Papers of the American Chemical Society, 200: 56-Inorganic Part 1 (1990).

38. K. Dehnicke and J. Strahle, Angew. Chem., Int. Ed. Engl., 20, 413 (1981).

39. C.J. Jones, J.A. McCleverty, B.D. Neaves and S.J. Reynolds, J. Chem. Soc., Dalton Trans., 733 (1986).

40. J.A. McCleverty, G. Denti and S. Reynolds, J. Chem. Soc., Dalton Trans., 81 (1993).

41. W. L. Madison, SMART Diffractometer Control Software, Bruker Analytical X-ray Instruments Inc., 1998.

42. W.L. Madison, SAINT Integration Software, Siemens Analytical X-ray Instruments Inc., 1994.

43. G.M. Sheldrick, SADABS: A Program for Absorption Correction with the Siemens SMART System; 1996.

44. W.L. Madison, SHELXTL Program System Version 5.1; Bruker Analytical X-ray Instruments Inc., 1998.

45. International Tables for Crystallography, Kluwer, Dordrecht, 1992.

46. M.B. Kassim, R. Paul, J.C. Jeffery, J.A. McCleverty and M.D. Ward, Inorg. Chim. Acta., 327, 160 (2002).

TMCH 5972 